\title{
Development
}

\section{Increased RET Activity Coupled with a Reduction in the RET Gene Dosage Causes Intestinal Aganglionosis in Mice}

\author{
Mitsumasa Okamoto, Toshihiro Uesaka, Keisuke Ito, and ${ }^{-H i d e k i}$ Enomoto
}

https://doi.org/10.1523/ENEURO.0534-20.2021

Division for Neural Differentiation and Regeneration, Department of Physiology and Cell Biology, Kobe University Graduate School of Medicine, Kobe 650-0017, Japan

\begin{abstract}
Mutations of the gene encoding the RET tyrosine kinase causes Hirschsprung's disease (HSCR) and medullary thyroid carcinoma (MTC). Current consensus holds that HSCR and MTC are induced by inactivating and activating RET mutations, respectively. However, it remains unknown whether activating mutations in the RET gene have adverse effects on ENS development in vivo. We addressed this issue by examining mice engineered to express RET51(C618F), an activating mutation identified in MTC patients. Although Ret ${ }^{\text {1(C618F/51(C618F) }}$ mice displayed hyperganglionosis of the ENS, Ret ${ }^{51(\mathrm{C} 618 \mathrm{~F}) /-}$ mice exhibited severe intestinal aganglionosis because of premature neuronal differentiation. Reduced levels of glial cell-derived neurotrophic factor (GDNF), a RET-activating neurotrophic factor, ameliorated the ENS phenotype of Ret $t^{51(C 618 F) /-}$ mice, demonstrating that GDNF-mediated activation of RET51(C618F) is responsible for severe aganglionic phenotype. The RET51(C618F) allele showed genetic interaction with Ednrb gene, one of modifier genes for HSCR. These data reveal that proliferation and differentiation of ENS precursors are exquisitely controlled by both the activation levels and total dose of RET. Increased RET activity coupled with a decreased gene dosage can cause intestinal aganglionosis, a finding that provides novel insight into HSCR pathogenesis.
\end{abstract}

Key words: cell signaling; enteric nervous system; Hirschsprung's disease; neuronal differentiation; RET

\section{Significance Statement}

Mutations of the RET gene have been identified in Hirschsprung's disease (HSCR) and neuroendocrine tumors (NET). It has been thought that HSCR and NET are caused by inactivating and activating mutations of the RET gene, respectively. However, little is known about whether enhanced RET activity exerts any roles in the pathogenesis of HSCR. We show that mice carrying an activating mutation in the Ret gene display intestinal aganglionosis when the Ret gene dosage is halved. The aganglionosis phenotype is caused by premature neuronal differentiation and impaired migration of ENS precursors. These findings raise the possibility that RET-activating mutations can cause HSCR when associated with a reduction in the dosage or expression of the RET gene.

\section{Introduction}

RET is a receptor tyrosine kinase that serves as a signaling receptor for the glial cell-derived neurotrophic factor (GDNF) family ligands (GFLs; Baloh et al., 2000; Airaksinen and Saarma, 2002). Binding of GFLs to their

Received December 8, 2020; accepted April 13, 2021; First published May 6, 2021.

The authors declare no competing financial interests. cognate GFR $\alpha$ receptors induces dimerization and subsequent autophosphorylation of RET, culminating in the activation of downstream intracellular signaling. RET is expressed in a wide variety of neural crest (NC)-derived cell types and endoderm-derived thyroid $\mathrm{C}$ cells. In

Author contributions: T.U. and H.E. designed research; M.O., T.U., and K.I. performed research; M.O., T.U., K.I., and H.E. analyzed data; H.E. contributed unpublished reagents/analytic tools; H.E. wrote the paper. 
humans, mutations in the RET gene are associated with the pathogenesis of various forms of diseases that include Hirschsprung's disease (HSCR) and medullary thyroid carcinoma (MTC). Hereditary MTCs occurs in multiple endocrine neoplasia (MEN)2, which is further subcategorized into MEN2A, MEN2B, and familial MTC (FMTC) based on the phenotype such as pheochromocytoma, hyperparathyroidism and/or other developmental anomalies (infertility, marfanoid habitus, etc.; Wells et al., 2013; Tomuschat and Puri, 2015).

HSCR is characterized by the congenital loss of enteric ganglia in the distal portion of the gut (intestinal aganglionosis). Genetic studies have revealed that HSCR is a multifactorial disease that involves mutations in multiple genes for its pathogenesis and exhibits complex patterns of inheritance. To date, mutations have been identified in as many as 17 genes (Tilghman et al., 2019), among which the RET gene is most frequently mutated (Amiel et al., 2008). HSCR-associated RET mutations have been identified throughout the RET genome, affecting both coding and non-coding regions. Coding mutations account for only $50 \%$ of familial and $15 \%$ of sporadic cases of HSCR (Edery et al., 1994; Romeo et al., 1994). Meanwhile, some non-coding variants that potentially affect the enhancer activity of the RET gene are considered necessary, albeit not sufficient, mutations in isolated HSCR cases (Kapoor et al., 2015). Thus, HSCR is a complex genetic trait in which reduced RET expression confers susceptibility to the disease.

In contrast to HSCR, MEN2 displays rather simple genetic features. Most of those mutations affects a restricted cysteine residue in the extracellular domain of RET, converting it to arginine, tyrosine or phenylalanine. These amino acid conversions disrupt intra-molecular cysteine bonding and causes aberrant intermolecular bonding and successive auto-phosphorylation of RET, leading to its aberrant and ligand-independent activation. Those RET mutations are likely sufficient for the development of tumors because familial MEN2 cases demonstrate autosomal dominant inheritance (Margraf et al., 2009).

Together, HSCR-associated and MTC-associated RET mutations display distinct features, and, although the whole spectrum of biological effects by those RET mutations have not been fully elucidated, current consensus holds that HSCR is caused by inactivating mutations of the RET gene whereas MTC is induced by activating mutations of RET (Hansford and Mulligan, 2000).

This work was supported by Japan Society for the Promotion of Science, Japan, Grants 17H03550, 17K19527, and 16K08466; Grant-in-Aid for Scientific Research on Innovative Areas "Stem Cell Aging and Disease" 25115002 from MEXT; the Takeda Science Foundation; and the Yakult BioScience Foundation.

Acknowledgements: We thank Hazuki Hiraga for editing this manuscript.

Correspondence should be addressed to Hideki Enomoto at enomotoh@ med.kobe-u.ac.jp.

https://doi.org/10.1523/ENEURO.0534-20.2021

Copyright @ 2021 Okamoto et al.

This is an open-access article distributed under the terms of the Creative Commons Attribution 4.0 International license, which permits unrestricted use, distribution and reproduction in any medium provided that the original work is properly attributed.
Although previous studies support that inactivation or downregulation of RET signaling leads to HSCR-like intestinal aganglionosis in mice, it has not been clear whether activating mutations of RET have adverse effects on ENS development (Amiel et al., 2008). To address this issue, we examined the development of the ENS in mice engineered to express RET C618F, one of the MTC-associated RET-activating mutants, under the endogenous Ret promoter (Okamoto et al., 2019). Biochemical studies revealed that RET $\mathrm{C} 618 \mathrm{~F}$ displays slightly higher RET basal phosphorylation than normal, but still requires GDNF for its full activation (Okamoto et al., 2019). Thus, RET C618F mutant mice are an ideal platform to understand how the ENS develops when the activity of RET is slightly elevated. We found that, in mice carrying the RET C618F mutation, the ENS phenotype changed dramatically from hyperganglionosis to aganglionosis when the Ret gene dosage was changed from two copies to one copy. Premature neuronal differentiation of ENS precursors contributed to the aganglionosis phenotype. Our findings reveal a novel mechanism of HSCR pathogenesis that is Ret-activating mutations can cause HSCR when the Ret gene dosage is reduced.

\section{Materials and Methods}

\section{Mice}

The generation and characterization of Ret51 and Ret51(C618F) mice have been described previously (Okamoto et al., 2019). We obtained Ret ${ }^{G F P}$ (a kind gift from J. Milbrandt, Washington University School of Medicine; Jain et al., 2006), Gdnf ${ }^{+/-}$(a kind gift from V. Pachnis The Francis Crick Institute, London, UK; Moore et al., 1996), and Ednrb ${ }^{f l e x 3}$ mice (a kind gift from M. L. Epstein, University of Wisconsin-Madison; Druckenbrod et al., 2008). Ednrb ${ }^{+/-}$mice were obtained by crossing Ednrb $^{f l e x 3}$ mice to Actb::Cre mice (stock \#019099; The Jackson Laboratory; Lewandoski et al., 1997).

Mice were bred and maintained at the Institute of Experimental Animal Research of Kobe University Graduate School of Medicine under specific pathogen-free conditions and all animal experiments were performed according to the Kobe University Animal Experimentation Regulations.

\section{Whole-mount immunostaining}

Dissected gut from embryos or postnatal day $(P) 0$ pups were fixed with $4 \%$ paraformaldehyde (PFA) in PBS containing $10 \mathrm{~mm}$ phosphate buffer, $\mathrm{pH}$ 7.4, $137 \mathrm{~mm}$ sodium chloride, and $2.7 \mathrm{~mm}$ potassium chloride overnight at $4{ }^{\circ} \mathrm{C}$ and incubated in $1 \%$ Triton $\mathrm{X}-100$ in PBS for $30 \mathrm{~min}$ at room temperature. After fixation and permeabilization, the preparations were incubated in $0.1 \mathrm{~m}$ glycine in PBS for 2$6 \mathrm{~h}$ and processed for immunohistochemistry. For the preparations from PO pups, blocking solution contains $5 \%$ skim milk, 5\% DMSO, $1 \%$ Tween 20 in PBS. The following antibodies were used: guinea pig anti-Phox $2 \mathrm{~b}$ (1:1000, home-made, raised against the C-terminal region of Phox2b (RRID:AB_2313690; Pattyn et al., 1997), goat anti-Sox10 (1:300, catalog \#sc-17342, Santa Cruz Biotechnology Inc., RRID: AB_2195374), rabbit anti- 
PGP9.5 (1:1000, catalog \#RA-95 101, Ultra Clone, RRID: AB_2313685), rabbit anti-phospho-ERK1/2 (1:500, catalog \#9101, Cell Signaling Technology, RRID: AB_331646), and chicken anti-GFP (1:1000, catalog \#GFP-1020, Aves Laboratories, RRID: AB_10000240). We used the following secondary antibodies (Biotium): CF488A donkey anti-rabbit IgG (catalog \#20015, RRID: AB_10559669), CF488A donkey anti-chicken IgY (catalog \#20166, RRID: AB_10854387), CF568 donkey anti-guinea-pig lgG (catalog \#20377), CF568 donkey anti-goat IgG (catalog \#20106, RRID: AB_ 10559672), CF568 donkey anti-rabbit lgG (catalog \#20098, RRID: AB_10557118), and CF640T donkey anti-goat IgG (catalog \#20179, RRID: AB_10853145).

Whole-mount gut 5-ethynyl-2'-deoxyuridine (EdU) assays

Embryonic day (E)12.5 or E14.5 pregnant females were injected intraperitoneally with EdU ( $50 \mu \mathrm{g} / \mathrm{g}$ body weight). Two hours after injection, dissection of gut was followed by fixation and permeabilization in the same fashion as whole-mount immunostaining. The preparations were washed twice for 3 min with $3 \%$ BSA in PBS at room temperature. For EdU assays (Click.iT Plus EdU Imaging kit, Invitrogen), the reaction cocktail (reaction buffer, $\mathrm{CuSO}_{4}$, Alexa Flour 594 azide and buffer additive as per manufacture's protocol) was added for $30 \mathrm{~min}$ followed by rinsing twice for $3 \mathrm{~min}$ with $3 \% \mathrm{BSA}$ in PBS in the dark at the room temperature. After EdU labeling, whole-mount immunostaining was performed as described above.

\section{Cell counts}

Phox $2 \mathrm{~b}^{+}$neurons were counted on ten sections per investigated region of the gut at $\mathrm{P} 0$. Phox $2 \mathrm{~b}^{+}$and $\mathrm{EdU}^{+}$Phox $2 \mathrm{~b}^{+}$ENS precursors were counted in a minimum of five areas at even intervals of the midgut longitudinally $\left(0.025 \mathrm{~mm}^{2}\right.$ each) and the rate of ENS precursor proliferation was determined in animals for each genotype.

\section{Experimental design and statistical analysis}

Images were carefully selected to show the average effect obtained for each experimental condition. All descriptive statistics are presented as means \pm SEM. Normality of the data were tested with Levene's test (SPSS II Statistics software; SPSS Inc.), and differences were subsequently assessed using unpaired $t$ test. If assumptions for a parametric test were not met (Levene's test, $p<0.05$ ), unpaired $t$ test with Welch correction was used. Statistical analyses for enteric neuron numbers were performed using one-way analysis of variance (ANOVA), followed by pairwise comparisons (Tukey's post hoc test) where appropriate. GraphPad Prism 5 software (GraphPad Software Inc.) was used to conduct unpaired $t$ test with Welch correction, one-way ANOVA with Tukey test and $\chi^{2}$ test. Animals of both sexes were used. No methods were used for sample size determination.

\section{Results}

\section{RET(C618F) enhances proliferation of ENS precursors and causes intestinal hyperganglionosis}

To understand the biological impact of enhanced RET signaling on ENS development, we examined mice expressing RET(C618F), a MEN2-associated RET-activating mutant. Previous studies revealed that, among MEN2associated RET mutants, those affecting RET(C618) residues display moderate to low transforming activity in vitro (Carlomagno et al., 1997; Ito et al., 1997). Our biochemical characterization indicated that RET(C618F) displays slightly higher basal phosphorylation than normal and requires GDNF for its full phosphorylation (Okamoto et al., 2019). Because RET(C618F) retains GDNF-responsiveness and exhibits moderate activation of RET-signaling, RET(C618F) is an ideal RET mutant to examine the effect of slight RET-signaling enhancement on ENS development. Since mice expressing RET(C618F) were engineered to express RET51(long isoform) cDNA carrying a C618F mutation by the endogenous Ret promoter, the mutant allele is hereafter referred to as $51(\mathrm{C} 618 \mathrm{~F})$. As a control, mice expressing wild-type RET51 cDNA were used (the allele referred to as 51). Ret $t^{51(\mathrm{C} 618 \mathrm{~F}) / 51(\mathrm{C} 618 \mathrm{~F})}$ mice were born apparently normally at an expected Mendelian ratio but all died of unknown causes within $24 \mathrm{~h}$ after birth (Okamoto et al., 2019). In newborn (P0) $\operatorname{Ret}^{51(\mathrm{C} 618 \mathrm{~F}) / 51(\mathrm{C} 618 \mathrm{~F})}$ mice, histologic analysis of the gut revealed that the density of enteric neurons in the myenteric layer of the small intestine appeared higher in $\operatorname{Ret}^{51(C 618 F) / 51(C 618 F)}$ mice than $R e t^{51 / 51}$ mice (control; Fig. 1A). Neuronal count confirmed a significant increase in the numbers of myenteric neurons in both small intestine and colon of Ret $t^{51(C 618 F) / 51(C 618 \mathrm{~F})}$ mice $(p<0.0001$; Fig. 1B).

We investigated proliferation of ENS precursors by antiPhox $2 \mathrm{~b}$ staining (which detects almost all ENS precursors during mid-gestation) combined with EdU labeling at E12.5 (a period of ENS precursor migration) and E14.5 (a period when ENS precursor migration is completed). This analysis revealed an increase in double-positive cell populations in $\operatorname{Ret}^{51(\mathrm{C} 618 \mathrm{~F}) / 51(\mathrm{C} 618 \mathrm{~F})}$ embryos as compared with $R e t^{51 / 51}$ embryos in both of these developmental periods $\left[\operatorname{Ret}^{51(\mathrm{C} 618 \mathrm{~F}) / 51(\mathrm{C} 618 \mathrm{~F})}\right.$ vs $\operatorname{Ret}^{51 / 51}$ in the midgut; $43.3 \pm 2.9 \%$ vs $31.7 \pm 0.6 \% \quad(p=0.019)$ at $E 12.5$ and $13.9 \pm 2.1 \%$ vs $10.2 \pm 0.9 \%(p=0.046)$ at $\mathrm{E} 14.5$, respectively; Fig. $1 C, D]$. Thus, the increase in enteric neuron numbers in newborn Ret ${ }^{51(\mathrm{C} 618 \mathrm{~F}) / 51(\mathrm{C} 618 \mathrm{~F})}$ mice is attributed at least in part to enhanced proliferation of ENS progenitors.

Previous studies suggested that reduced RET signaling impairs ENS migration (Young et al., 2001; Natarajan et al., 2002; Uesaka et al., 2008) and that proliferation of ENS precursors is a major driving force for ENS migration (Landman et al., 2007). We therefore examined the migration of ENS precursors in Ret $t^{51(C 618) / 51(C 618)}$ embryos. Unexpectedly, the migratory wavefront of ENS precursors was always slightly delayed in $\operatorname{Ret}^{51(\mathrm{C} 618 \mathrm{~F}) / 51(\mathrm{C} 618 \mathrm{~F})} \mathrm{em}$ bryos as compared with control embryos at E12.5 (Fig. 2, upper panel). However, this delay was only transient and compensated for before birth. The ENS was fully developed in all of $R e t^{51(\mathrm{C} 618 \mathrm{~F}) / 51(\mathrm{C} 618 \mathrm{~F})}$ neonates (Fig. 2, lower panel).

In adult $\operatorname{Ret}^{51(\mathrm{C} 618 \mathrm{~F}) /+}$ mice, we detected focal hyperplasia of thyroid C cells (Okamoto et al., 2019), a precancerous condition that leads to MTC (Wolfe et al., 1973). 


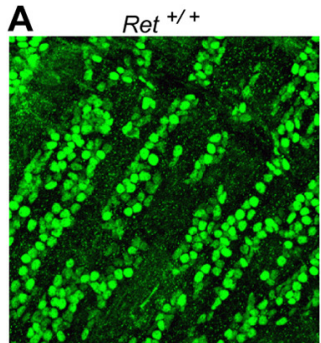

B

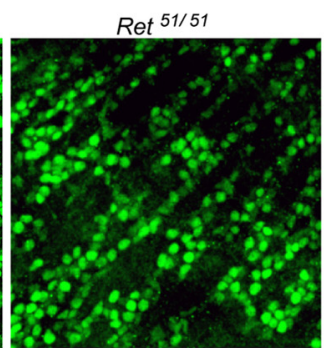

Phox $2 b$
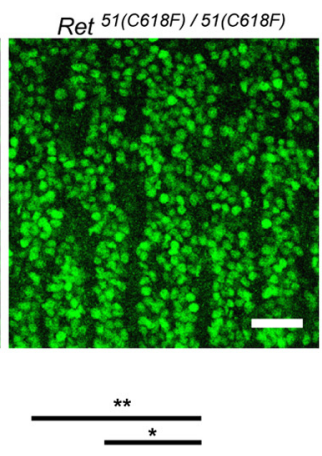

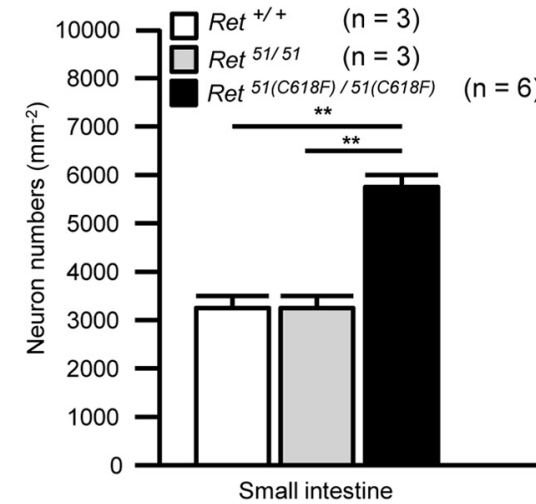

C

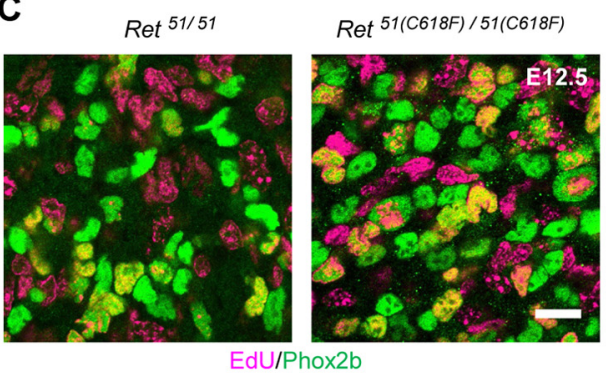

$\square \operatorname{Ret}^{51 / 51 \quad(\mathrm{n}=3)}$

$\square \operatorname{Ret}^{51(\mathrm{C} 618 \mathrm{~F}) / 51(\mathrm{C} 618 \mathrm{~F})}$
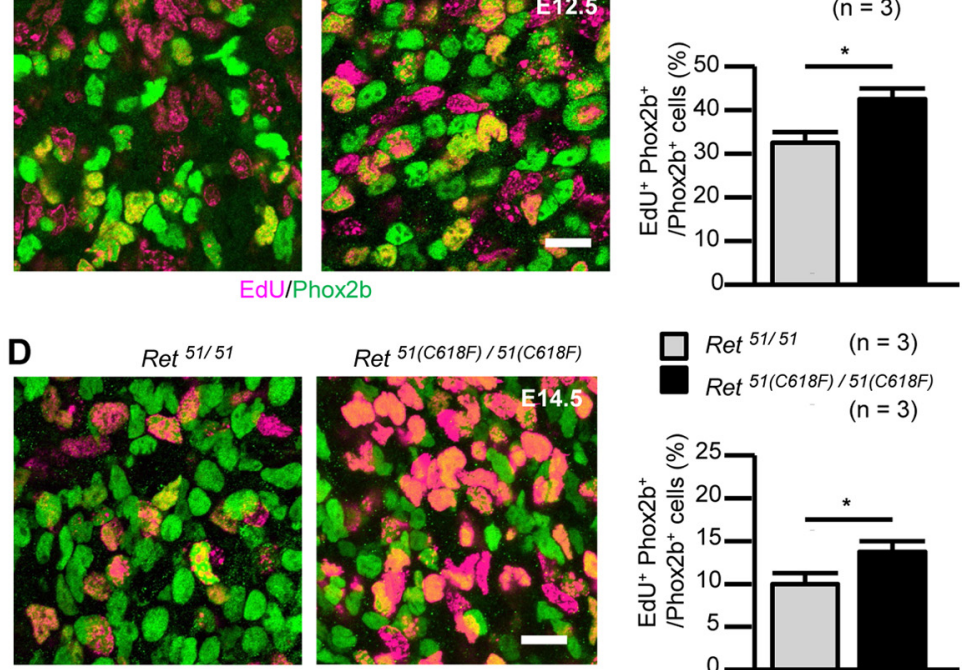

$(n=3)$

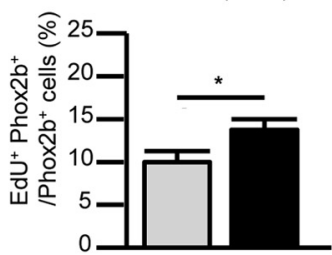

Figure 1. Ret $t^{51(\mathrm{C} 618 \mathrm{~F}) / 51(\mathrm{C} 618 \mathrm{~F})}$ mice display hypertrophy of enteric ganglia. A, Whole-mount Phox2b staining (green) of enteric neurons in the myenteric plexus of the small intestine from PO Ret $t^{+/+}$, Ret ${ }^{51 / 51}$, and Ret ${ }^{51(C 618 F) / 51(C 618 F)}$ mice. B, Quantification of Phox $2 \mathrm{~b}^{+}$enteric neuron numbers in the small intestine and the colon from PO $\operatorname{Ret}^{+/+}(n=3), \operatorname{Ret}^{51 / 51}(n=3)$, and $\operatorname{Ret}^{51(\mathrm{C} 618 F) / 51(\mathrm{C} 618 F)}$ $(n=6)$ mice; ${ }^{*} p=0.001,{ }^{* *} p<0.0001$, one-way ANOVA with Tukey's post hoc test. $\boldsymbol{C}, \boldsymbol{D}$, Detection of EdU (magenta) incorporated into Phox2b ${ }^{+}$ENS precursors (green) in the midgut from E12.5 (C) and E14.5 (D) Ret ${ }^{51 / 51}$ and Ret ${ }^{51(C 6187 / 51(C 618)}$ fetuses. The gut was labeled by a 2-h pulse of EdU. The graphs (right panels) display the rate of ENS precursor proliferation at E12.5 and $14.5 \operatorname{Ret}^{51 / 51}(n=3)$ and $\operatorname{Ret}^{51(C 618 F) / 51(C 618 F)}(n=3)$ fetuses; ${ }^{*} p<0.05$, unpaired $t$ test. Scale bars: $50 \mu \mathrm{m}(\boldsymbol{A})$ and $20 \mu \mathrm{m}(\boldsymbol{C}, \boldsymbol{D})$.

Together, these results indicate that, consistent with its enhanced activity in vitro, RET51(C618F) confers gain-of-function effects on development of the ENS and thyroid $\mathrm{C}$ cells.

\section{$\operatorname{Ret}^{51(C 618 F) /-}$ mice display intestinal aganglionosis}

We moved on to examine the effects of a reduction in the dosage of the RET gene because reduced RET expression is known to confer susceptibility to intestinal aganglionosis in both human and mice (Emison et al., 2005; Uesaka et al., 2008). We crossed $R e t^{51 / 51}$ or $R e t^{51(C 618 F) / 51(C 618 F)}$ mice to Ret ${ }^{E G F P /+}$ mice in which one of the Ret alleles was replaced by the Ret-EGFP allele (Ret null). Consistent with previous observations that one allele of wild-type RET-expressing allele is 

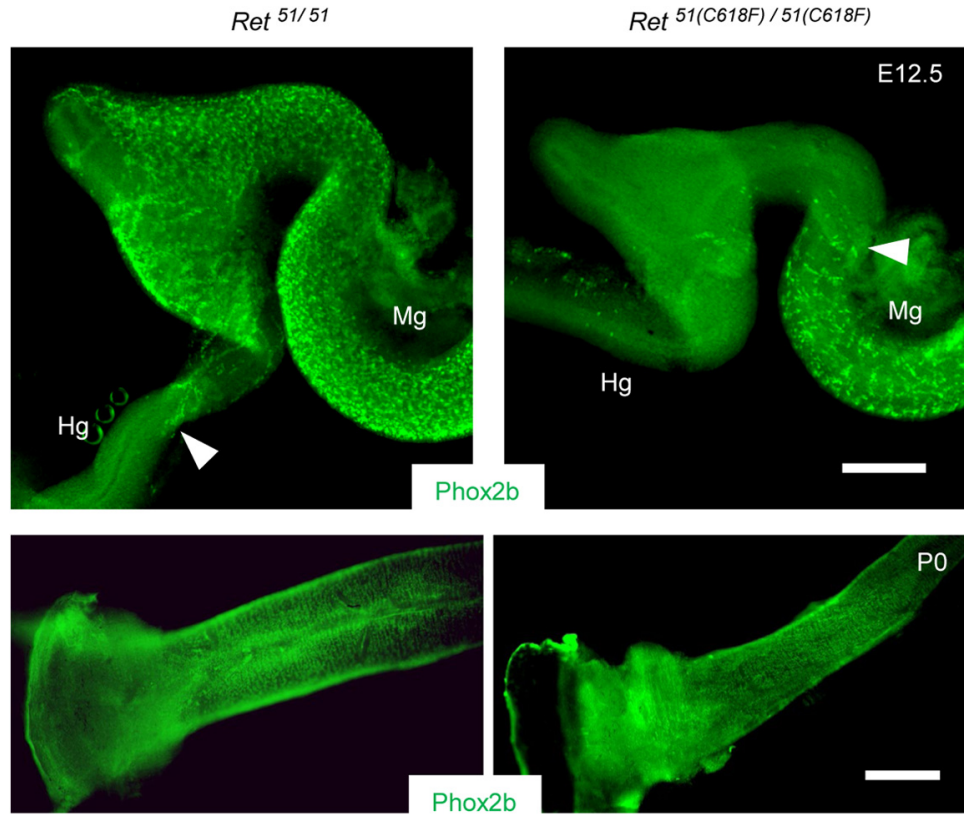

Figure 2. $\operatorname{Ret}^{51(\mathrm{C} 618 \mathrm{~F} / 51(\mathrm{C} 618 \mathrm{~F})}$ mice exhibit complete gut colonization by ENS precursors. Phox2b-labeled ENS precursors and neurons (green) in the developing gut in $R e t^{51 / 51}$ and $R e t^{51(C 618 F) / 51(C 618 F)}$ mice at E12.5 (upper panels) and P0 (lower panels). Migration of ENS precursors is slightly delayed at E12.5, but gut colonization by them is completed at P0. Arrowheads depict the front of the migrating ENS precursors. Hg, hindgut; Mg, midgut. Scale bars: $250 \mu \mathrm{m}$ (upper panels) and $500 \mu \mathrm{m}$ (lower panels).

sufficient for normal development of the ENS in mice, the gut was fully furnished with ENS meshwork in Ret ${ }^{51 / E G F P}$ mice (Fig. $3 A, B$, left). In a stark contrast, all of $\operatorname{Ret}^{51(C 618 F) / E G F P}$ mice displayed intestinal aganglionosis (Fig. 3B). This result was surprising, as $\operatorname{Ret}^{51(\mathrm{C} 618 \mathrm{~F}) / 51(\mathrm{C} 618 \mathrm{~F})}$ mice display hyperganglionosis (Fig. 1A). Although the length of aganglionic gut was varied, in $\sim 62 \%$ of $\operatorname{Ret}^{51(\mathrm{C} 618 \mathrm{~F}) / \mathrm{EGFP}}$ mice (29 out of 34 mice examined), the ENS was present only in the small intestine (Fig. 3C). Among these mice, eight mice (20\% of all examined) displayed skip segment-type aganglionosis (Fig. 3B, third picture). This skip segment appears to be developed at least partially because of impaired migration of trans-mesenteric ENS progenitors, a cell population primarily contributing to colonic ENS (Nishiyama et al., 2012), because we occasionally found a limited number of enteric neurons scattered in the colon in some of $\operatorname{Ret}^{51(C 618 F) / E G F P}$ embryos at
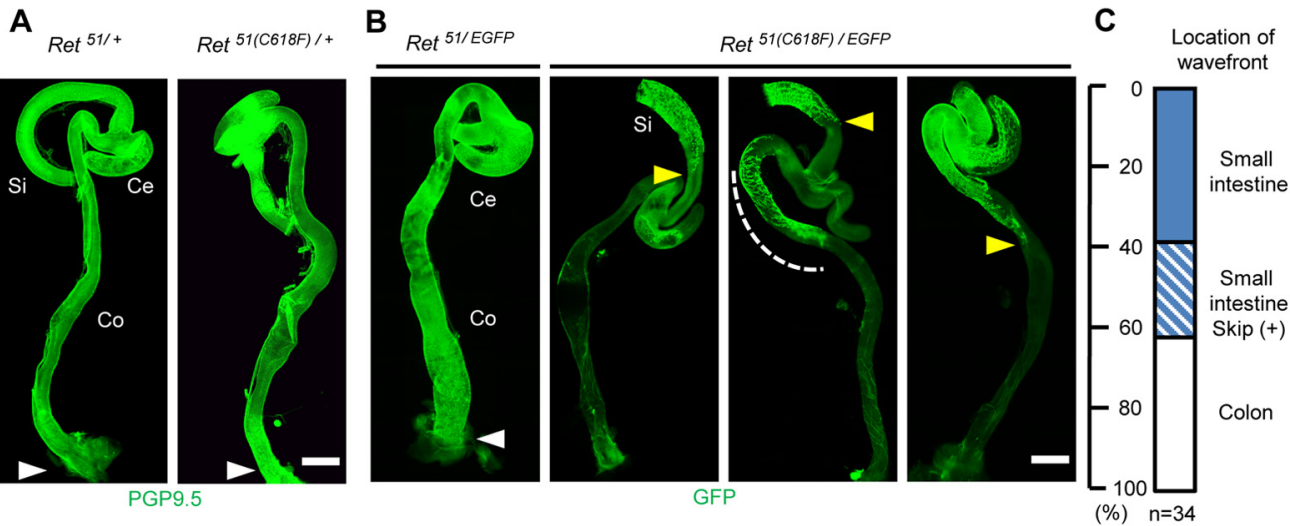

Figure 3. $\operatorname{Ret}^{51(\mathrm{C} 618 F) /-}$ mice exhibit intestinal aganglionosis. $\boldsymbol{A}, \boldsymbol{B}$, Whole-mount images of the enteric neurons stained with antiPGP-9.5 (A) or labeled by GFP $(\boldsymbol{B})$ in P0 Ret ${ }^{51 /+}$ and $\operatorname{Ret}^{51(\mathrm{C} 618 \mathrm{~F}) /+}, \operatorname{Ret}^{51 / \mathrm{EGFP}}$, and Ret $t^{51(\mathrm{C} 618 \mathrm{~F}) / \mathrm{EGFP}}$ gut. Complete gut colonization by ENS cells was seen in $R e t^{51 /+}, \operatorname{Ret}^{51(\mathrm{C} 618 \mathrm{~F}) /+}$, and Ret ${ }^{51 / E G F P}$ mice (white arrowheads), while Ret $t^{51(C 618 F) / E G F P}$ mice exhibited disrupted colonization of the gut by ENCCs. The wavefront (yellow arrowheads) was defined as the most caudal continuous strands of $\mathrm{EGFP}^{+}$cells. Some Ret ${ }^{51(\mathrm{C} 618 \mathrm{~F}) / E G F P}$ mice show skip segment aganglionosis where small regions of the colon contain enteric ganglia (white dotted region). $\boldsymbol{C}$, The proportion of three types of aganglionic phenotype (small intestinal, skip segment, and colonic aganglionosis). Ce, cecum; Co, colon; Si, small intestine. Scale bars: $1 \mathrm{~mm}(\boldsymbol{A}, \boldsymbol{B})$. 
A

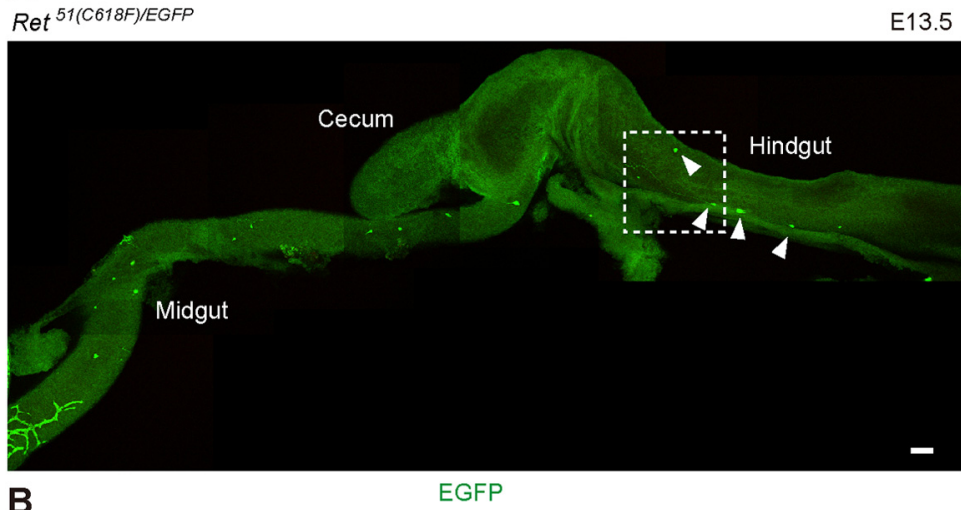

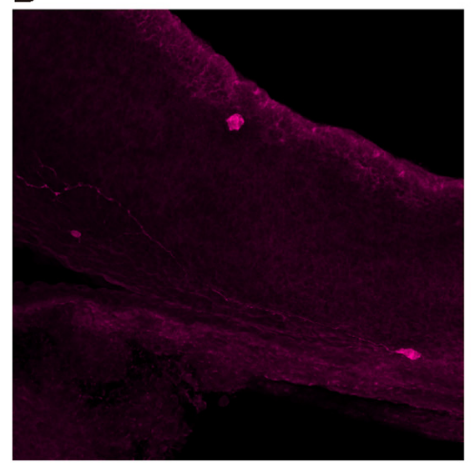

PGP9.5

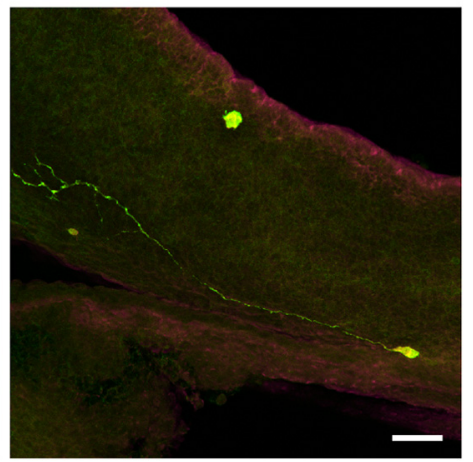

EGFP/PGP9.5

Figure 4. Detection of a few enteric neurons in the hindgut of Ret ${ }^{51(C 618 F) / E G F P}$ embryos. Whole-mount preparation of embryonic gut showing the presence of a few differentiating enteric neurons $(\boldsymbol{A}$, inset) revealed by anti-PGP9.5 antibody $(\boldsymbol{B})$. Scale bars: $100 \mu \mathrm{m}$ (A) and $50 \mu \mathrm{m}(\boldsymbol{B})$.

E13.5, a period $2 \mathrm{~d}$ after trans-mesenteric migration is completed (Fig. 4). These data demonstrate that RET51(C618F) allele causes severe intestinal aganglionosis when the RET gene dosage is reduced to half.

\section{Premature neuronal differentiation impairs migration of ENS progenitors in $\operatorname{Ret}^{51(\mathrm{C} 618 \mathrm{~F}) / \mathrm{EGFP}}$ embryos}

To investigate the mechanism underlying the impaired ENS development in $\operatorname{Ret}^{51(C 618 F) / E G F P}$ mice, we conducted whole-mount immunohistochemical analyses of embryonic gut (E12.5). In control (Ret ${ }^{51 / E G F P}$ ) embryos, ENS progenitors at the migrating wavefront invaded the proximal colon and expressed both RET (revealed by GFP fluorescence) and Sox10 (Fig. 5A, left), indicating those cells are immature progenitors. Consistent with this expression pattern, none of the cells at the wavefront expressed PGP9.5 (Fig. 5B, left), a marker for neuronal differentiation. In contrast, in Ret $t^{51(C 618 F) / E G F P}$ embryos, Sox10 expression was lost in many cells at the wavefront (Fig. 5A, right, arrowheads). Associated with this change, we found aberrant expression of PGP9.5 in ENS progenitors at the migratory wavefront, which was located primarily in the midgut (Fig. 5B, right). These results indicate that premature neuronal differentiation is induced in ENS progenitors at the migratory wavefront in $\operatorname{Ret}^{51(C 618) / E G F P}$ embryos.
A previous study revealed that elevation of ERK activity is associated with induction of neuronal differentiation in ENS progenitors (Uesaka et al., 2013). We examined ERK activation by whole-mount staining of embryonic gut (E12.5) using anti-phospho-Erk (pErk) antibodies. In $\operatorname{Ret}^{51 / E G F P}$ embryos, pErk-positive ENS progenitors were abundant in proximal regions of the midgut, whereas such cells were almost undetectable at the wavefront region (Fig. 5C, right upper panels). In contrast, pErk-positive cells were frequently observed not only in the proximal midgut but also in the wavefront regions in $\operatorname{Ret}^{51(C 618 F) / E G F P}$ embryos (Fig. 5C, left and right bottom panels). These data collectively indicate that single alleleonly expression of RET51(C618F) causes premature enteric neuronal differentiation in vivo.

\section{GDNF-mediated activation of RET51(C618F) is responsible for premature neuronal differentiation of ENS progenitors}

Previous biochemical analyses revealed that RET51 (C618F) responds to GDNF and displays enhanced phosphorylation in vitro. To investigate whether GDNF-induced stimulation of RET51(C618F) contributes to severe aganglionosis phenotype in $\operatorname{Ret}^{51(\mathrm{C} 618 \mathrm{~F}) /+}$ mice, we examined whether severity of the phenotype changes in $\operatorname{Ret}^{51(C 618 F) / E G F P}$ mice on Gdnf $f^{+/}$background. By wholemount GFP staining of the neonatal gut $(n=20)$, we found 
A

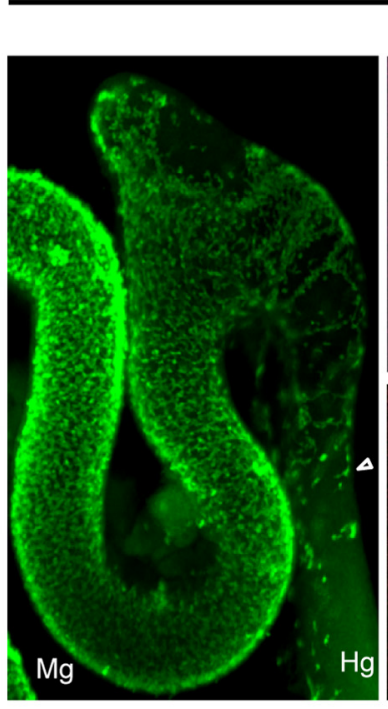

GFP
Ret 51/EGFP

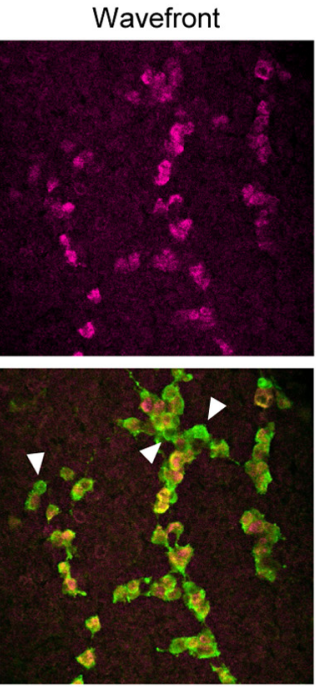

GFP/Sox10
Ret 51(C618F)/EGFP

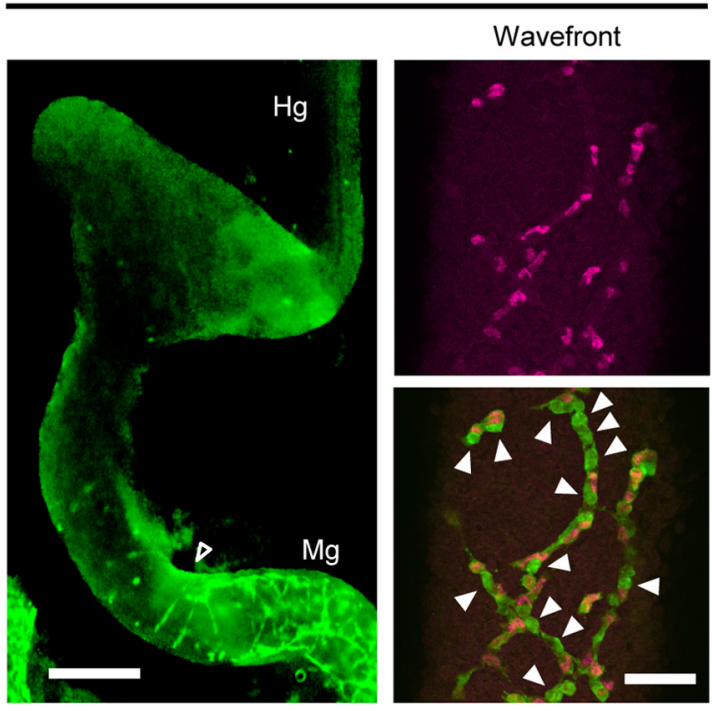

GFP

GFP/Sox10

B

Ret 51/EGFP

Ret 51(C618F) / EGFP
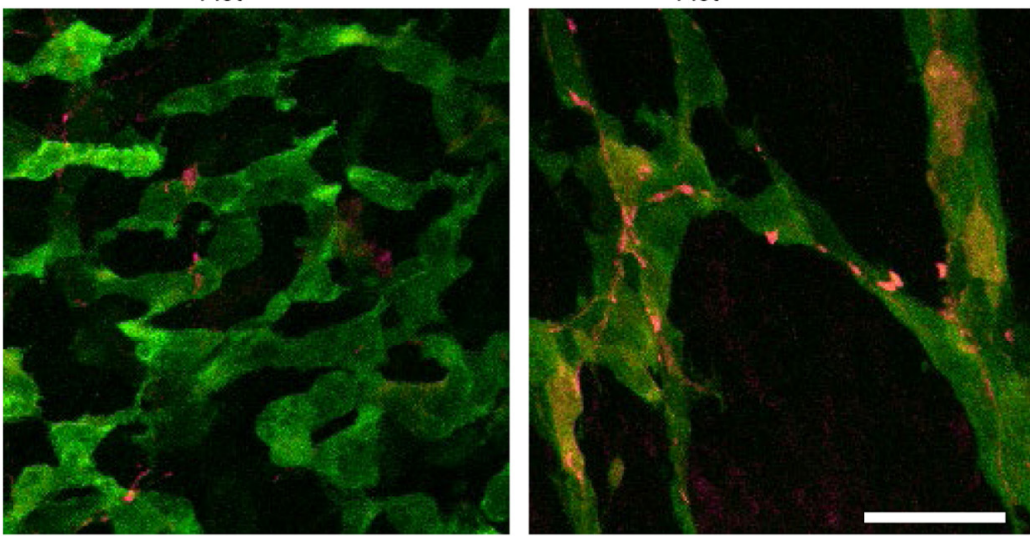

C

GFP/PGP9.5

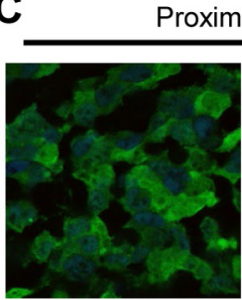

Proximal midgut

Wavefront

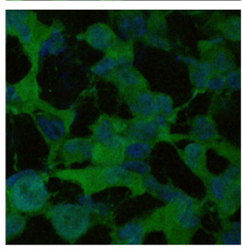

GFP/Sox 10
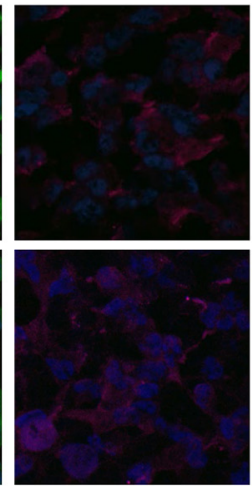

pERK/Sox10

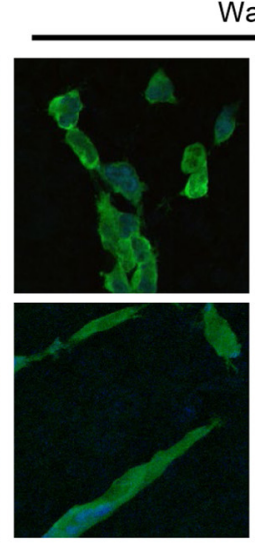

GFP/Sox10

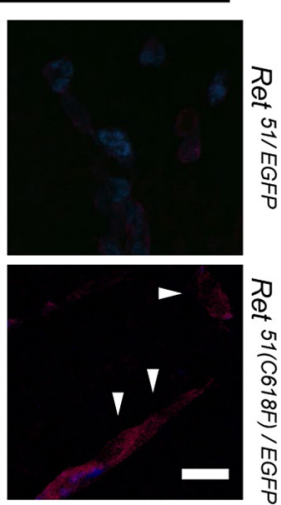

pERK/Sox10

Figure 5. Reduced RET51(C618) expression leads to premature differentiation of ENS precursors at the migratory wavefront. $\boldsymbol{A}$, Whole-mount images of GFP-labeled cells in the gut from E12.5 $\operatorname{Ret}^{51 / E G F P}$ and $\operatorname{Ret}^{51(C 618 F) / E G F P}$ embryos (left panels). GFP ${ }^{+}$cells in

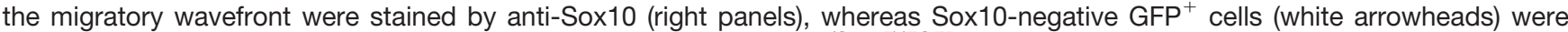
found at the delayed migratory wavefront (open arrowhead) of $\operatorname{Ret}^{51(C 618 F) / E G F P}$ gut. $\boldsymbol{B}$, Whole-mount images of GFP-labeled cells stained with anti-PGP9.5 in E12.5 Ret ${ }^{51 / E G F P}$ and Ret ${ }^{51(C 618 F) / E G F P}$ gut. PGP9.5-labeled GFP ${ }^{+}$cells were detected at the delayed migratory wavefront of Ret ${ }^{51(C 618 F) / E G F P}$ gut. C, Immunohistochemical staining for GFP (green), Sox10 (blue), and activated ERK (pERK, magenta) in ENS cells of Ret ${ }^{51 / E G F P}$ and Ret ${ }^{51(C 618 F) / E G F P}$ embryos at E12.5. In the migratory wavefront of Ret ${ }^{51(C 618 F) / E G F P}$ 
continued

embryos, pERK was mainly observed in $\mathrm{GFP}^{+}$and Sox10- differentiating neurons (white arrowheads). Hg, hindgut; Mg, midgut. Scale bars: $250 \mu \mathrm{m}(\boldsymbol{A}$, left panel), $50 \mu \mathrm{m}(\boldsymbol{A}$, right panel), $25 \mu \mathrm{m}(\boldsymbol{B})$, and $20 \mu \mathrm{m}(\boldsymbol{C})$.

that most of $\operatorname{Ret}^{51(\mathrm{C} 618 F) / E G F P} / \mathrm{Gdnf}^{+/-}$mice (80\%) displayed colonic aganglionosis (Fig. 6A), which stood in a sharp contrast to the ENS phenotype of $\operatorname{Ret}^{51(C 618 F) / E G F P}$ that showed mostly extensive aganglionosis (aganglionic segment exceeding to the small intestine). $\chi^{2}$ test of independence confirmed the significant differences between $\operatorname{Ret}^{51(\mathrm{C} 618 \mathrm{~F}) / \mathrm{EGFP}} / \mathrm{Gdnf}^{+/-}$and $\operatorname{Ret}^{51(\mathrm{C} 618 \mathrm{~F}) / \mathrm{EGFP}} / \mathrm{Gdnf}^{+/+}$ mice $(p=0.005<0.01)$. Interestingly, in one case, the ENS was found fully developed up to the anal end (Fig. $6 B)$. Moreover, skip segment-type aganglionosis, which was identified in $24 \%$ of $R e t^{51(C 618 F) /-}$ mice, was not detected in any of $\operatorname{Ret}^{51(\mathrm{C} 618 \mathrm{~F}) / \mathrm{EGFP}} / \mathrm{Gdnf}^{+/-}$mice. These results collectively indicate that reduction in GDNF levels exerts significant rescue effects on severe aganglionosis phenotype (Fig. 6A,B).

At E12.5, migration of ENS precursors was delayed in

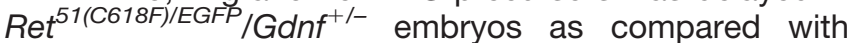
$R e t^{51 / E G F P} / \mathrm{Gdnf}^{+/-}$embryos (Fig. 6C). To examine the effect of the reduction of Gdnf gene dosage on intracellular signaling, whole-mount pERK staining was performed on
A Ret $51 /$ EGFP
$/$ Gdnf $^{+/-}$

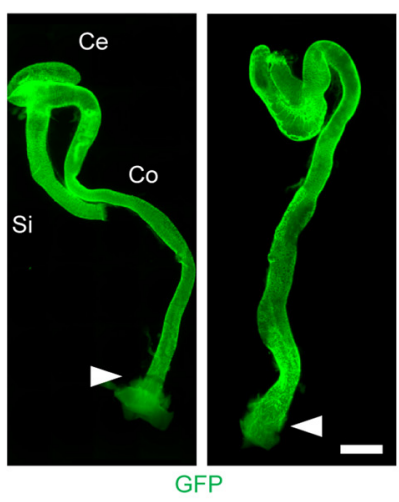

B

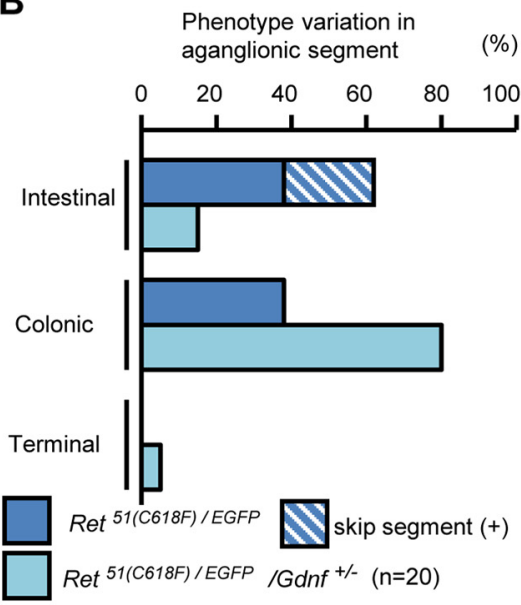

C

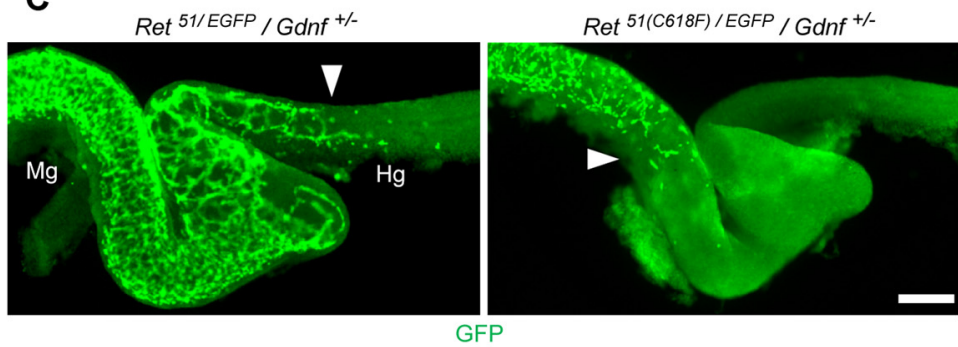

D Ret $^{51(\mathrm{C} 618 \mathrm{~F}) / \mathrm{EGFP} / \mathrm{Gdnf}}{ }^{+/-}$

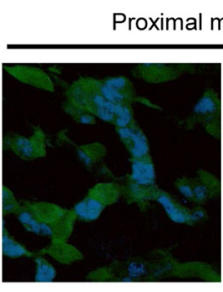

GFP/Sox10

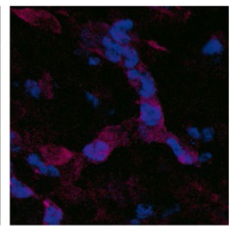

pERKISOX10

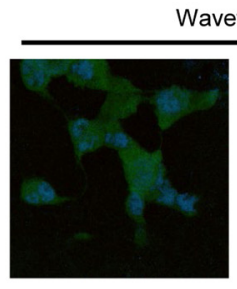

GFPISOX10
Wavefront

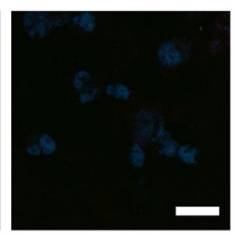

pERKISOX10

Figure 6. Reducing Gdnf gene dosage moderately rescues ENS phenotype of Ret ${ }^{51(C 618 F) /-}$ mice. $\boldsymbol{A}$, Representative images of P0 $\operatorname{Ret}^{51 / E G F P} / \mathrm{Gdnf}^{+/-}$and $\operatorname{Ret}^{51(\mathrm{C} 618 \mathrm{~F}) / E G F P} / \mathrm{Gdnf}^{+/-}$large intestine showing complete colonization with GFP-positive enteric neurons. $\boldsymbol{B}$, Comparison of ENS wavefront location between Ret ${ }^{51(\mathrm{C} 618 \mathrm{~F}) / E G F P}$ and Ret ${ }^{51(\mathrm{C} 618 \mathrm{~F}) / E G F P} / \mathrm{Gdnf} \mathrm{f}^{+/-}$mice at P0. Reduction of Gdnf gene dosage significantly ameliorated the severity of enteric aganglionosis ( $\chi^{2}$ test, $\left.p<0.01\right)$. $\boldsymbol{C}$, Representative images of E12.5 $\operatorname{Ret}^{51 / E G F P} / \mathrm{Gdnf}^{+/-}$and $\operatorname{Ret}^{51(\mathrm{C} 618 F) / E G F P} / \mathrm{Gdnf}^{+/-}$gut displaying colonization by GFP-positive ENS precursors. White arrowheads indicate the location of ENS precursor wavefront. $\boldsymbol{D}$, Whole-mount GFP, Sox10, and pERK pathway stainings of ENS cells of $\operatorname{Ret}^{51(\mathrm{C} 618 F) / E G F P} / \mathrm{Gdnf}^{+/-}$embryos at E12.5. Activation of ERK was not observed in ENS precursors at the migratory wavefront. Ce, cecum; Co, colon; Si, small intestine; Hg, hindgut; Mg, midgut. Scale bars: $1000 \mu \mathrm{m}(\boldsymbol{A}), 250 \mu \mathrm{m}(\boldsymbol{C})$, and $20 \mu \mathrm{m}(\boldsymbol{D})$. 
the gut of $\operatorname{Ret}^{51(\mathrm{C} 618 F) / E G F P} / \mathrm{Gdnf}^{+/-}$embryos (E12.5). Similar to wild-type or Ret ${ }^{51 / E G F P}$ embryos (Fig. 4C, top), ERK phosphorylation was undetectable at the wavefront regions of $\operatorname{Ret}^{51(\mathrm{C} 618 F) / E G F P} / \mathrm{Gdnf}^{+/-}$embryos (Fig. 6D, right). These data reveal that GDNF-mediated activation of RET51(C618F) is responsible for aberrant phosphorylation of ERK in ENS precursors at the wavefront and causes intestinal aganglionosis in $R e t^{51(\mathrm{C} 618 \mathrm{~F}) /-}$ embryos.

\section{An allelic loss of the Ednrb gene exacerbates the ENS phenotype of Ret ${ }^{51(C 618 F) /-}$ mice}

Previous studies revealed a genetic interaction between the Ret and Ednrb genes in HSCR pathogenesis. Either Ret heterozygosity or the Ednrb /s/ls allele alone exerts no adverse effect on ENS development, but induces severe intestinal aganglionosis when combined (Carrasquillo et al., 2002). Ednrb signaling regulates multiple processes of ENS development including migration, proliferation and differentiation of ENS precursors (Barlow et al., 2003; Kruger et al., 2003). We examined a potential genetic interaction between the Ret51(C618F) allele and the Ednrb gene by crossing $\operatorname{Ret}^{51 / 51(\mathrm{C} 618 \mathrm{FF})}$ mice to $\mathrm{Ednrb}^{+/-} / \operatorname{Ret}^{E G F P /+}$ mice. We found that, in contrast to Ret $^{51 / E G F P} /$ Ednrb $^{+/-}$embryos, which displayed normal ENS development, $\operatorname{Ret}^{51(C 618 F) / E G F P} /$ Ednrb $^{+/-}$embryos exhibited severe intestinal aganglionosis in which the ENS is observed only in the proximal part of the small intestine (Fig. 7A-C). Immunohistochemical examination of ENS precursors revealed robust phosphorylation of ERK and loss of Sox10 expression at the wavefront regions (Fig. 7D). Thus, reduction of one copy of the Ednrb gene leads to exacerbation of the aganglionosis phenotype, which contrasted the ameliorating effect by the reduction of the Gdnf gene dosage. This difference is not caused by the differential expression levels of GFR $\alpha 1$, the cognate receptor for GDNF involved in HSCR pathogenesis (Lui et al., 2002), as it was expressed at comparable levels in $\mathrm{Gdnf}^{+-}, \mathrm{Ednrb}^{+/-}$, and wild-type embryos (Fig. 7E). At any rate, these results reveal a clear genetic interaction between the Ret51 (C618F) allele and the Ednrb gene and suggest that the Ednrb signaling functions to inhibit premature differentiation of ENS precursors in this context.

\section{Discussion}

In this study, we have provided evidence that RET (C618F), a RET-activating mutant, causes intestinal aganglionosis when the Ret gene copy number is reduced to half, which is contrary to the current consensus that enteric aganglionosis is caused by inactivating RET mutations. This unexpected finding provides novel insights into mechanisms underlying the development of the ENS by RET/GDNF signaling and the pathogenesis of HSCR.

The involvement of RET activating mutations in HSCR was first described in co-segregation of MEN2A/FMTC and HSCR in a fraction of families. These patients carry missense mutations in the RET gene, which substitutes arginine or serine for a cysteine residue at position 618 or 620 . These RET mutants display ligand-independent constitutive activation because of intermolecular di-sulfide- linked dimerization (Santoro et al., 1995) and simultaneously loses cell surface expression (Asai et al., 1995). The former property contributes to neoplastic pathology including MTC and pheochromocytoma, whereas the latter contributes to impaired development of the ENS (HSCR). Therefore, in the context of ENS development, these mutants (C618R, C618S and C620R) behave as RET-inactivating mutants (Mulligan et al., 1994; Borst et al., 1995). Animal studies support this notion, as mice harboring RET (C620R) mutation in a homozygous fashion display kidney agenesis and intestinal aganglionosis, a phenotype identical to that of Ret-deficient mice (Carniti et al., 2006; Yin et al., 2007). RET(C618F) examined in this study exhibited distinct properties. Unlike other C618 or C620 mutants, RET(C618F) is expressed on the cell surface (Okamoto et al., 2019). Although phosphorylation levels of RET(C618F) are slightly higher than those of wild-type RET, GDNF stimulation further enhances phosphorylation of RET (C618F) (Okamoto et al., 2019). Thus, RET(C618F) is a GDNF-responsive RET-activating mutant. Consistent with these biochemical properties, $\operatorname{Ret}^{51(\mathrm{C} 618 \mathrm{~F}) / 51(\mathrm{C} 618 \mathrm{~F})}$ mice had increased numbers of enteric neurons because of enhanced proliferation of ENS precursors. Surprisingly, despite the activating nature of RET51(C618F), Ret ${ }^{51(\mathrm{C} 618 \mathrm{~F}) /-}$ mice displayed severe intestinal aganglionosis, in sharp contrast to Ret ${ }^{R E T 51 /-}$ mice (control), which exhibited no ENS deficit. This study provides evidence, for the first time to our knowledge, that RET-activating mutations can cause intestinal aganglionosis when coupled with a reduction in the Ret gene dosage.

It is important to note that, the RET C618F allele displays genetic interaction with the Ednrb gene, which is known as a modifier gene for HSCR carrying mutations in the RET gene. Our findings suggest a novel pathogenetic mechanisms of HSCR by revealing how reduced RET expression affects ENS development and confers susceptibility to HSCR (Emison et al., 2005). It is also important to note that many of $\operatorname{Ret}^{51(\mathrm{C} 618 \mathrm{~F}) /-}$ mice displayed skip-segment aganglionosis. Ret ${ }^{51(\mathrm{C} 618 \mathrm{~F}) /-}$ mice thus serve as the first valuable platform to investigate the molecular and cellular mechanisms underlying this mysterious condition.

Histologic examination of $\operatorname{Ret}^{51(\mathrm{C} 618 \mathrm{~F}) /-}$ embryos revealed that premature neuronal differentiation of ENS precursors is likely to be the cause of the intestinal aganglionosis. Exacerbation of the aganglionic phenotype by the reduction of the Ednrb gene supports this possibility because endothelin-3/Ednrb signaling prevents premature neuronal differentiation (Wu et al., 1999). The aganglionic phenotype of $\operatorname{Ret}^{51(\mathrm{C618F)/-}}$ embryos stands in sharp contrast to that of $\operatorname{Ret}^{51(\mathrm{C} 618 \mathrm{~F}) / 51(\mathrm{C} 618 \mathrm{~F})}$ embryos, in which ENS precursors underwent proliferation rather than differentiation. Although the exact mechanism by which ENS precursors adopt to a different cell fate (proliferation or differentiation) is unknown, it may involve regulation of Erk phosphorylation. In PC12 cells, EGF treatment enhances cell proliferation, while FGF treatment induces neuronal differentiation. This difference in cell fate is tightly associated with the levels and kinetics of Erk phosphorylation. EGF evokes a rapid surge and subsequent abrupt quenching of Erk phosphorylation, whereas FGF induces 
A

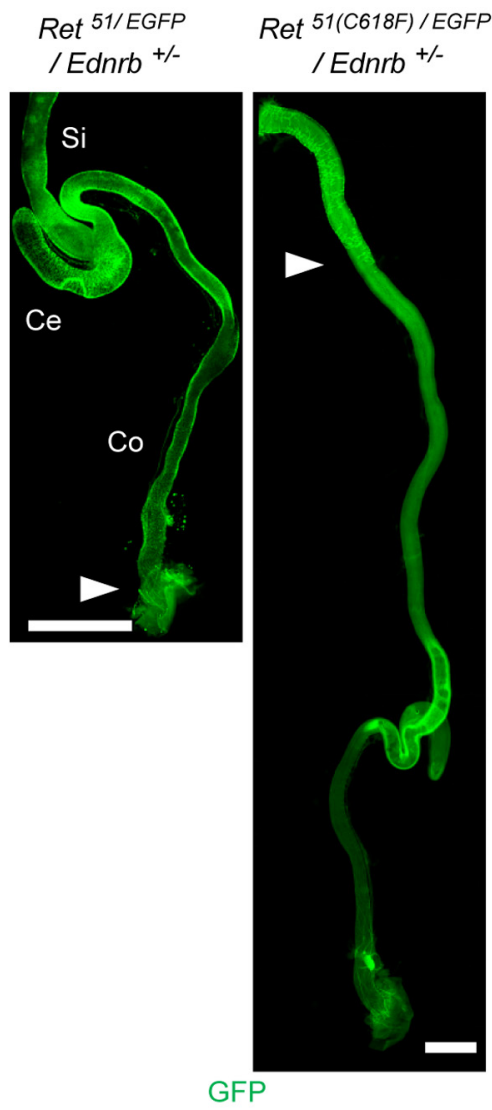

E

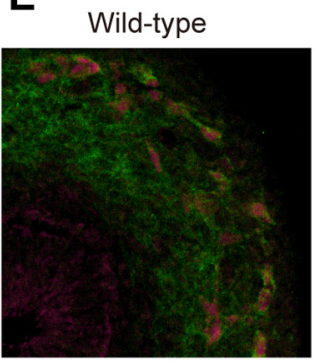

B
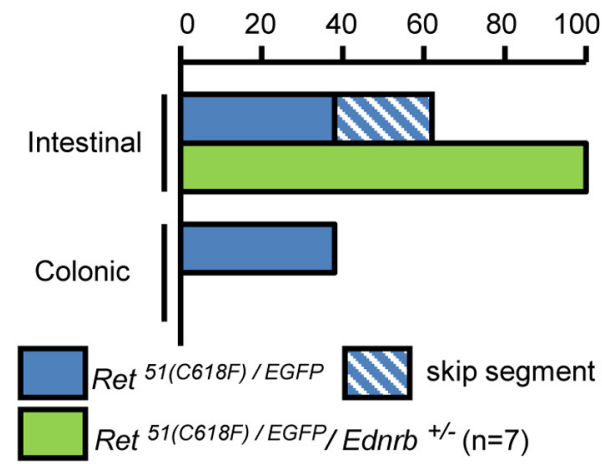

Ret $51(\mathrm{C} 618 \mathrm{~F}) / \mathrm{EGFP}$

$\operatorname{Ret}^{51(C 618 F) / E G F P / E d n r b}{ }^{+/-}(\mathrm{n}=7)$

\section{C $\operatorname{Ret}^{51(\mathrm{C} 618 \mathrm{~F}) / E G F P} / \mathrm{Ednrb}^{+/-}$}

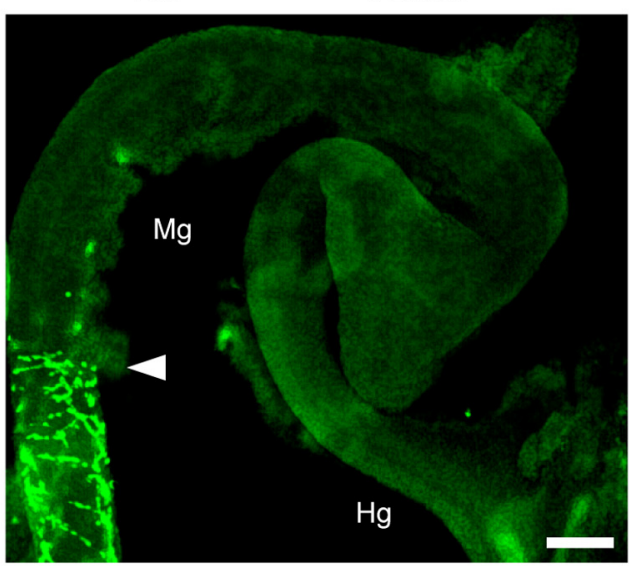

GFP
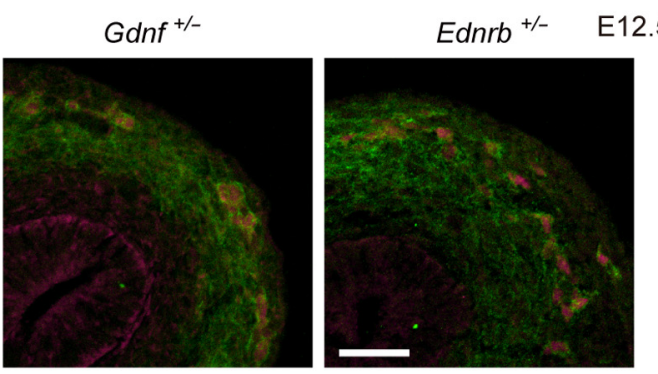

12.5

GFR $\alpha 1 / P h o x 2 b$

D Ret 51 (C618F)/EGFP / Ednrb ${ }^{+/-}$

Proximal midgut

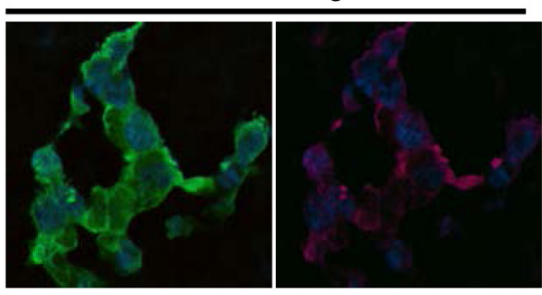

GFP/Sox10

PGP9.5/Sox10

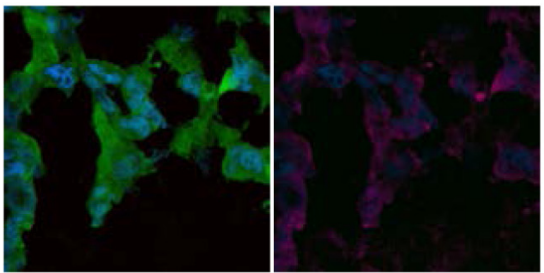

GFP/Sox10

$\mathrm{pERK} / \mathrm{Sox} 10$

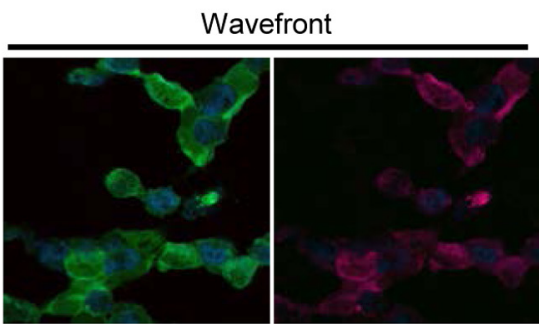

GFP/Sox10

PGP9.5/Sox10

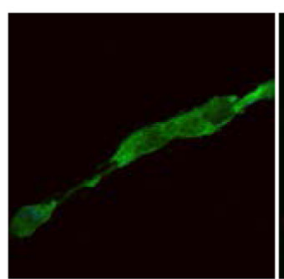

GFP/Sox 10

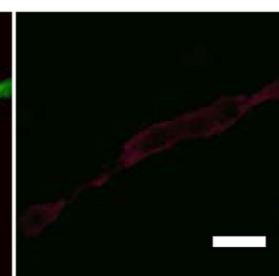

$\mathrm{pERK} / \operatorname{Sox} 10$

Figure 7. The severity of interruption of the ENS migration depends on the Ednrb gene dosage in $R E T^{51(C 618 F) /-}$ mice. $\boldsymbol{A}$, Wholemount GFP staining of PO Ret $t^{51 / E G F P} / E_{d n r b}{ }^{+/-}$and $\operatorname{Ret}^{51(C 618 F) / E G F P} / E d n r b^{+/-}$gut. White arrowheads indicate the location of wavefront of enteric neurons. B, Comparison of location of ENS wavefront between Ret ${ }^{51(C 618 F) / E G F P}$ and Ret ${ }^{51(C 618 F) / E G F P} /$ Ednrb $^{+/-}$mice at P0. Reduction of Ednrb gene dosage increased the severity of enteric aganglionosis of Ret ${ }^{51(C 618 F) / E G F P}$ mice. $\boldsymbol{C}$, Whole-mount GFP staining of the enteric neurons in E12.5 Ret $^{51(C 618 F) / E G F P} / E d n r b^{+/-}$gut. White arrowhead indicates location of the wavefront of ENS precursors. D, Whole-mount GFP, PGP9.5, Sox10, and pERK pathway stainings of ENS cells of Ret ${ }^{51(C 618 F) / E G F P \text {, }}$ $E_{d n r b^{+1-}}$ embryos at E12.5. Activation of ERK was observed in ENS precursors at the migratory wavefront. $\boldsymbol{E}$, Immunohistochemical detection of GFR $\alpha 1$ (green) in ENS progenitors (whose nuclei marked in magenta by anti-Phox $2 \mathrm{~b}$ antibody) of wild-type, Gdnf ${ }^{+/}$, and Ednrb ${ }^{+/-}$embryos (E12.5). Ce, cecum; Co, colon; Si, small intestine; Hg, hindgut; Mg, midgut. Scale bars: $1 \mathrm{~mm}(\boldsymbol{A}), 250 \mu \mathrm{m}(\boldsymbol{C})$, and $20 \mu \mathrm{m}(\boldsymbol{D}), 50 \mu \mathrm{m}(\boldsymbol{E})$.

long-lasting and moderate levels of Erk phosphorylation (Qiu and Green, 1991; Traverse et al., 1992; Nguyen et al., 1993). Interestingly, Erk phosphorylation-associated cell fate determination in ENS precursors was reported previously (Natarajan et al., 2002; Asai et al., 2006;
Goto et al., 2013). We can therefore assume that Erk activity is differentially regulated in ENS precursors between $\operatorname{Ret}^{51(\mathrm{C} 618 \mathrm{~F}) / 51(\mathrm{C} 618 \mathrm{~F})}$ and $\operatorname{Ret}^{51(\mathrm{C} 618 \mathrm{~F}) /-}$ embryos. We tried to examine this possibility by culturing ENS precursors and conducting biochemical analyses. 
Unfortunately, however, $\operatorname{Ret}^{51(\mathrm{C} 618 F) /-}$ ENS precursors displayed a tendency to differentiate in vitro, and we were unable to obtain reliable data. To understand the mechanisms underlying the intestinal aganglionosis in $\operatorname{Ret}^{51(\mathrm{C} 618 F) /-}$ mice, we also have to understand the biochemical properties of RET51(C618F) in more detail. Although RET51(C618F) is expressed on cell surface, it is also detected in the cytoplasm (Okamoto et al., 2019). The latter likely reflects localization in ER, which is commonly observed in all MEN-associated RET mutant proteins (Wagner et al., 2012). Thus, RET51(C618F) has combined properties of wild-type RET and MENassociated RET mutants. Even on the cell surface, it is unknown whether RET51(C618F) behaves as wild-type RET. For instance, on GDNF binding to GFR $\alpha$ receptors, wild-type RET protein gets recruited to the raft and phosphorylated, which provides a platform to activate Src and Akt-PI3 kinase efficiently. It is currently unknown how RET51(C618F) is localized and activates intracellular signaling molecules on the cell surface. In these respects, RET51(C618F) may not reflect enhanced activity of purely wild-type RET. RET51(C618F) has unique biochemical properties among MEN-associated RET mutants, which suggest that all of RET-activating mutations do not necessarily cause the intestinal aganglionosis by RET gene dosage reduction.

Amelioration of the phenotype in Ret ${ }^{51(\mathrm{C} 618 F) /-} \mathrm{em}$ bryos by the Gdnf gene reduction indicates that GDNFmediated activation of RET51(C618F) is responsible for the severe aganglionic phenotype. Although NRTN also activates RET in developing ENS (Heuckeroth et al., 1998), contribution of NRTN-mediated RET(C618F) activation to the aganglionic phenotype is unlikely because expression of GFR $\alpha 2$, the cognate receptor for NRTN, occurs later than a period when the aganlionic phenotype in $R e t^{51(C 618 F) /-}$ embryos becomes obvious. It is important to note that, in normal ENS development, enteric neuron numbers are determined primarily by the levels of GDNF signaling. Mice heterozygous for the GDNF-deficient allele $\left(\mathrm{Gdnf}^{+/-}\right.$mice) display reduced numbers of enteric neurons (Gianino et al., 2003). In contrast, reduction of Sprouty2, an inhibitor of Erk phosphorylation downstream of RET/GDNF signaling, leads to hyperganglionosis of the gut (Taketomi et al., 2005). This hyperganglionosis phenotype is suppressed on $\mathrm{Gdnf}^{+/-}$background. Evidence also suggests that RET expression is regulated by RET activity induced by GDNF (Oppenheim et al., 2000). Taken together, both signaling and expression of RET are exquisitely controlled by the availability of GDNF, Sprouty2 and phosphor-Erk. Even a slight disturbance (both upregulation and downregulation) of RET signaling can abrogate ENS development (Nagy et al., 2020). Understanding the development and developmental disorders of the ENS requires the elucidation of interactions among these molecules.

\section{References}

Airaksinen MS, Saarma M (2002) The GDNF family: signalling, biological functions and therapeutic value. Nat Rev Neurosci 3:383-394.
Amiel J, Sproat-Emison E, Garcia-Barcelo M, Lantieri F, Burzynski G, Borrego S, Pelet A, Arnold S, Miao X, Griseri P, Brooks AS, Antinolo G, de Pontual L, Clement-Ziza M, Munnich A, Kashuk C, West K, Wong KK, Lyonnet S, Chakravarti A, et al. (2008) Hirschsprung disease, associated syndromes and genetics: a review. J Med Genet 45:1-14.

Asai N, Iwashita T, Matsuyama M, Takahashi M (1995) Mechanism of activation of the ret proto-oncogene by multiple endocrine neoplasia 2A mutations. Mol Cell Biol 15:1613-1619.

Asai N, Fukuda T, Wu Z, Enomoto A, Pachnis V, Takahashi M, Costantini F (2006) Targeted mutation of serine 697 in the Ret tyrosine kinase causes migration defect of enteric neural crest cells. Development 133:4507-4516.

Baloh RH, Enomoto H, Johnson EM Jr, Milbrandt J (2000) The GDNF family ligands and receptors - implications for neural development. Curr Opin Neurobiol 10:103-110.

Barlow A, de Graaff E, Pachnis V (2003) Enteric nervous system progenitors are coordinately controlled by the $\mathrm{G}$ protein-coupled receptor EDNRB and the receptor tyrosine kinase RET. Neuron 40:905-916.

Borst MJ, VanCamp JM, Peacock ML, Decker RA (1995) Mutational analysis of multiple endocrine neoplasia type $2 \mathrm{~A}$ associated with Hirschsprung's disease. Surgery 117:386-391.

Carlomagno F, Salvatore G, Cirafici AM, De Vita G, Melillo RM, de Franciscis V, Billaud M, Fusco A, Santoro M (1997) The different RET-activating capability of mutations of cysteine 620 or cysteine 634 correlates with the multiple endocrine neoplasia type 2 disease phenotype. Cancer Res 57:391-395.

Carniti C, Belluco S, Riccardi E, Cranston AN, Mondellini P, Ponder BA, Scanziani E, Pierotti MA, Bongarzone I (2006) The Ret(C620R) mutation affects renal and enteric development in a mouse model of Hirschsprung's disease. Am J Pathol 168:1262-1275.

Carrasquillo MM, McCallion AS, Puffenberger EG, Kashuk CS, Nouri N, Chakravarti A (2002) Genome-wide association study and mouse model identify interaction between RET and EDNRB pathways in Hirschsprung disease. Nat Genet 32:237-244.

Druckenbrod NR, Powers PA, Bartley CR, Walker JW, Epstein ML (2008) Targeting of endothelin receptor-B to the neural crest. Genesis 46:396-400.

Edery P, Lyonnet S, Mulligan LM, Pelet A, Dow E, Abel L, Holder S, Nihoul-Fékété C, Ponder BA, Munnich A (1994) Mutations of the RET proto-oncogene in Hirschsprung's disease. Nature 367:378380.

Emison ES, McCallion AS, Kashuk CS, Bush RT, Grice E, Lin S, Portnoy ME, Cutler DJ, Green ED, Chakravarti A (2005) A common sex-dependent mutation in a RET enhancer underlies Hirschsprung disease risk. Nature 434:857-863.

Gianino S, Grider JR, Cresswell J, Enomoto H, Heuckeroth RO (2003) GDNF availability determines enteric neuron number by controlling precursor proliferation. Development 130:2187-2198.

Goto A, Sumiyama K, Kamioka Y, Nakasyo E, Ito K, Iwasaki M, Enomoto H, Matsuda M (2013) GDNF and endothelin 3 regulate migration of enteric neural crest-derived cells via protein kinase $A$ and Rac1. J Neurosci 33:4901-4912.

Hansford JR, Mulligan LM (2000) Multiple endocrine neoplasia type 2 and RET: from neoplasia to neurogenesis. J Med Genet 37:817827.

Heuckeroth RO, Lampe PA, Johnson EM, Milbrandt J (1998) Neurturin and GDNF promote proliferation and survival of enteric neuron and glial progenitors in vitro. Dev Biol 200:116-129.

Ito S, Iwashita T, Asai N, Murakami H, Iwata Y, Sobue G, Takahashi M (1997) Biological properties of Ret with cysteine mutations correlate with multiple endocrine neoplasia type $2 \mathrm{~A}$, familial medullary thyroid carcinoma, and Hirschsprung's disease phenotype. Cancer Res 57:2870-2872.

Jain S, Encinas M, Johnson EM Jr, Milbrandt J (2006) Critical and distinct roles for key RET tyrosine docking sites in renal development. Genes Dev 20:321-333.

Kapoor A, Jiang Q, Chatterjee S, Chakraborty P, Sosa MX, Berrios C, Chakravarti A (2015) Population variation in total genetic risk of 
Hirschsprung disease from common RET, SEMA3 and NRG1 susceptibility polymorphisms. Hum Mol Genet 24:2997-3003.

Kruger GM, Mosher JT, Tsai YH, Yeager KJ, Iwashita T, Gariepy CE, Morrison SJ (2003) Temporally distinct requirements for endothelin receptor $B$ in the generation and migration of gut neural crest stem cells. Neuron 40:917-929.

Landman KA, Simpson MJ, Newgreen DF (2007) Mathematical and experimental insights into the development of the enteric nervous system and Hirschsprung's disease. Dev Growth Differ 49:277286.

Lewandoski M, Meyers EN, Martin GR (1997) Analysis of Fgf8 gene function in vertebrate development. Cold Spring Harb Symp Quant Biol 62:159-168.

Lui VC, Samy ET, Sham MH, Mulligan LM, Tam PK (2002) Glial cell line-derived neurotrophic factor family receptors are abnormally expressed in aganglionic bowel of a subpopulation of patients with Hirschsprung's disease. Lab Invest 82:703-712.

Margraf RL, Crockett DK, Krautscheid PM, Seamons R, Calderon FR, Wittwer CT, Mao R (2009) Multiple endocrine neoplasia type 2 RET protooncogene database: repository of MEN2-associated RET sequence variation and reference for genotype/phenotype correlations. Hum Mut 30:548-556.

Moore MW, Klein RD, Fariñas I, Sauer H, Armanini M, Phillips $H$, Reichardt LF, Ryan AM, Carver-Moore K, Rosenthal A (1996) Renal and neuronal abnormalities in mice lacking GDNF. Nature 382:76-79.

Mulligan LM, Eng C, Attié T, Lyonnet S, Marsh DJ, Hyland VJ, Robinson BG, Frilling A, Verellen-Dumoulin C, Safar A, et al. (1994) Diverse phenotypes associated with exon 10 mutations of the RET proto-oncogene. Hum Mol Genet 3:2163-2167.

Nagy N, Guyer RA, Hotta R, Zhang D, Newgreen DF, Halasy V, Kovacs T, Goldstein AM (2020) RET overactivation leads to concurrent Hirschsprung disease and intestinal ganglioneuromas. Development 147:dev190900.

Natarajan D, Marcos-Gutierrez C, Pachnis V, de Graaff E (2002) Requirement of signalling by receptor tyrosine kinase RET for the directed migration of enteric nervous system progenitor cells during mammalian embryogenesis. Development 129:5151-5160.

Nguyen TT, Scimeca JC, Filloux C, Peraldi P, Carpentier JL, Van Obberghen E (1993) Co-regulation of the mitogen-activated protein kinase, extracellular signal-regulated kinase 1 , and the $90-\mathrm{kDa}$ ribosomal S6 kinase in PC12 cells. Distinct effects of the neurotrophic factor, nerve growth factor, and the mitogenic factor, epidermal growth factor. J Biol Chem 268:9803-9810.

Nishiyama C, Uesaka T, Manabe T, Yonekura Y, Nagasawa T, Newgreen DF, Young HM, Enomoto H (2012) Trans-mesenteric neural crest cells are the principal source of the colonic enteric nervous system. Nat Neurosci 15:1211-1218.

Okamoto M, Yoshioka Y, Maeda K, Bito Y, Fukumoto T, Uesaka T, Enomoto H (2019) Mice conditionally expressing RET(C618F) mutation display $\mathrm{C}$ cell hyperplasia and hyperganglionosis of the enteric nervous system. Genesis 57:e23292.

Oppenheim RW, Houenou LJ, Parsadanian AS, Prevette D, Snider WD, Shen L (2000) Glial cell line-derived neurotrophic factor and developing mammalian motoneurons: regulation of programmed cell death among motoneuron subtypes. J Neurosci 20:50015011.

Pattyn A, Morin X, Cremer H, Goridis C, Brunet JF (1997) Expression and interactions of the two closely related homeobox genes
Phox2a and Phox2b during neurogenesis. Development 124:4065-4075.

Qiu MS, Green SH (1991) NGF and EGF rapidly activate p21ras in PC12 cells by distinct, convergent pathways involving tyrosine phosphorylation. Neuron 7:937-946.

Romeo G, Ronchetto P, Luo Y, Barone V, Seri M, Ceccherini I, Pasini $B$, Bocciardi $R$, Lerone $M$, Kääriäinen $H$, et al. (1994) Point mutations affecting the tyrosine kinase domain of the RET proto-oncogene in Hirschsprung's disease. Nature 367:377-378.

Santoro M, Carlomagno F, Romano A, Bottaro DP, Dathan NA, Grieco M, Fusco A, Vecchio G, Matoskova B, Kraus MH, et al. (1995) Activation of RET as a dominant transforming gene by germline mutations of MEN2A and MEN2B. Science 267:381-383.

Taketomi T, Yoshiga D, Taniguchi K, Kobayashi T, Nonami A, Kato R, Sasaki M, Sasaki A, Ishibashi H, Moriyama M, Nakamura K, Nishimura J, Yoshimura A (2005) Loss of mammalian Sprouty2 leads to enteric neuronal hyperplasia and esophageal achalasia. Nat Neurosci 8:855-857.

Tilghman JM, Ling AY, Turner TN, Sosa MX, Krumm N, Chatterjee S, Kapoor A, Coe BP, Nguyen KH, Gupta N, Gabriel S, Eichler EE, Berrios C, Chakravarti A (2019) Molecular genetic anatomy and risk profile of Hirschsprung's disease. N Engl J Med 380:14211432.

Tomuschat C, Puri P (2015) RET gene is a major risk factor for Hirschsprung's disease: a meta-analysis. Pediatr Surg Int 31:701710.

Traverse S, Gomez N, Paterson H, Marshall C, Cohen P (1992) Sustained activation of the mitogen-activated protein (MAP) kinase cascade may be required for differentiation of PC12 cells. Comparison of the effects of nerve growth factor and epidermal growth factor. Biochem J 288:351-355.

Uesaka T, Nagashimada M, Yonemura S, Enomoto H (2008) Diminished Ret expression compromises neuronal survival in the colon and causes intestinal aganglionosis in mice. $\mathrm{J}$ Clin Invest 118:1890-1898.

Uesaka T, Nagashimada M, Enomoto H (2013) GDNF signaling levels control migration and neuronal differentiation of enteric ganglion precursors. J Neurosci 33:16372-16382.

Wagner SM, Zhu S, Nicolescu AC, Mulligan LM (2012) Molecular mechanisms of RET receptor-mediated oncogenesis in multiple endocrine neoplasia 2. Clinics (Sao Paulo) 67:77-84.

Wells SA Jr, Pacini F, Robinson BG, Santoro M (2013) Multiple endocrine neoplasia type 2 and familial medullary thyroid carcinoma: an update. J Clin Endocrinol Metab 98:3149-3164.

Wolfe HJ, Melvin KE, Cervi-Skinner SJ, Saadi AA, Juliar JF, Jackson CE, Tashjian AH Jr (1973) C-cell hyperplasia preceding medullary thyroid carcinoma. N Engl J Med 289:437-441.

Wu JJ, Chen JX, Rothman TP, Gershon MD (1999) Inhibition of in vitro enteric neuronal development by endothelin-3: mediation by endothelin B receptors. Development 126:1161-1173.

Yin L, Puliti A, Bonora E, Evangelisti C, Conti V, Tong WM, Medard JJ, Lavoué MF, Forey N, Wang LC, Manié S, Morel G, Raccurt M, Wang ZQ, Romeo G (2007) C620R mutation of the murine ret proto-oncogene: loss of function effect in homozygotes and possible gain of function effect in heterozygotes. J Cancer 121:292300.

Young HM, Hearn CJ, Farlie PG, Canty AJ, Thomas PQ, Newgreen DF (2001) GDNF is a chemoattractant for enteric neural cells. Dev Biol 229:503-516. 